\title{
Use of inhaled sevoflurane in adult survivors of cardiac arrest
}

\author{
A Markota*, B Kit, R Gagič, A Sinkovič \\ From ESICM LIVES 2015 \\ Berlin, Germany. 3-7 October 2015
}

\section{Introduction}

Use of inhalation anesthetic sevoflurane has some potential advantages over intravenous sedation in adult survivors of cardiac arrest. Wake-up times are shorter compared to intravenous sedation, neurologic assessment could potentially be performed sooner and there are reports of possible protection against ischaemicreperfusion injury. There are no prospective studies or guidelines regarding use of sevoflurane in this setting.

\section{Objectives}

Our aim is to present a case series of adult survivors of cardiac arrest who were sedated with sevoflurane.

\section{Methods}

We performed a retrospective, single-centre study in a 12-bed tertiary medical intensive care unit.

\section{Results}

Our cohort comprised 12 patients who were admitted from November 2014 - April 2015. Mean age was $63.9 \pm$ 14.9 years, $9(75 \%)$ were men. Mean time from collapse to return of spontaneous circulation was $13 \pm 5$ min. Mean duration of sedation with sevoflurane was $2.5 \pm 2.4$ days. Five (42\%) patients survived and 3 (25\%) survived with Cerebral Performance Category 1 and 2. We recorded no self-extubations, one episode of unexpected awakening, no new onset hyperkalemia and no QT prolongation. Sevoflurane was discontinued in $2(17 \%)$ patients because of ventilation problems. Sevoflurane was used as the only during therapeutic hypothermia in all patients and as the only during mechanical ventilation sedative in $6(50 \%)$ patients. Propofol was used during mechanical ventilation simultaneously in $4(33 \%)$ patients and midazolam in $2(17 \%)$ patients. Transient increase in liver function tests

UKC Maribor, OIIM, Maribor, Slovenia was observed in 4 (33\%) patients. In all cases it was attributed to ischaemic hepatitis and liver function normalized within a week in all patients. Renal failure developed in $2(17 \%)$ patients and was attributed to circulatory shock in both patients.

\section{Conclusions}

Sedation with sevoflurane in adult survivors of cardiac arrest was feasible and safe. Prospective trials are needed to evaluate the role of sedation with sevoflurane in this patient population.

Published: 1 October 2015

doi:10.1186/2197-425X-3-S1-A746

Cite this article as: Markota et al:: Use of inhaled sevoflurane in adult survivors of cardiac arrest. Intensive Care Medicine Experimental 2015 3(Suppl 1):A746.
Submit your manuscript to a SpringerOpen ${ }^{\circ}$ journal and benefit from:

- Convenient online submission

- Rigorous peer review

- Immediate publication on acceptance

- Open access: articles freely available online

- High visibility within the field

- Retaining the copyright to your article

Submit your next manuscript at $>$ springeropen.com (c) 2015 Markota et al.; This is an Open Access article distributed under the terms of the Creative Commons Attribution License (http:// creativecommons.org/licenses/by/4.0), which permits unrestricted use, distribution, and reproduction in any medium, provided the original work is properly cited. 